Int. J. Electrochem. Sci., 14 (2019) 1024 - 1039

\title{
Study on the Under-Rib Convection for Improving in situ Reactants Supply and Water Discharge, hysteresis effect and Current Density Distributions for Polymer Electrolyte Fuel Cells
}

\author{
Hyung-Man Kim ${ }^{*}$ \\ Department of Mechanical Engineering \& High Safety Vehicle Core Technology Research Center, \\ INJE University, 607 Eobang-dong, Gimhae-si, Gyongsangnam-do 621-749, Republic of Korea \\ *E-mail: mechkhm@inje.ac.kr
}

doi: $10.20964 / 2019.01 .93$

Received: 31 July 2018 / Accepted: 16 October 2018 / Published: 30 November 2018

New flow-field design with the under-rib convection (URC) aims to enhance polymer electrolyte fuel cell (PEFC) performance. This paper presents the experimental and numerical results for single cells with a new flow-field that stimulates URC with additional sub-channels and by-passes to a conventional flow-field with 5-passes and 4-turns on an active area of $25 \mathrm{~cm}^{2}$. To characterize the role of under-rib convection for PEFC's polarization performance, the performance related parameters of in situ reactants and liquid water flows, hysteresis effects and current density distributions of a new serpentine flow-field with sub-channels and by-passes (SFFSB) were compared experimentally and numerically with those of conventional SFFs without SB (CASFF). Hysteresis curves of the new SFFSB design featured a considerably smaller area than those of the CASFF design, because hysteresis curves measure variation of polarization by electric load. The hysteresis effects of PEFCs were investigated between the SFF without and with sub-channels and by-passes (SBs) designs. In the single cell of a CASSF, the areas of hysteresis loops over five cycles were evaluated statistically, obtaining a polarization curve of 0.03836 \pm 0.001431 (mean \pm s.e.m.) and a power density curve of $0.02889 \pm 0.002181$. In the single cell of the new SFFSB, the area of hysteresis loops over five cycles was measured variation of polarization by electric load, obtaining a polarization curve of $0.03581 \pm 0.0006720$ and a power density curve of $0.02307 \pm 0.0005538$. In the experimental measurement of PEFC polarization curve, the average current density of the new SFFSB, $1.557 \mathrm{~A} / \mathrm{cm}^{2}$, was increased by $18.85 \%$ compared to that of the CASFF, $1.310 \mathrm{~A} / \mathrm{cm}^{2}$ at a cell's voltage of $0.35 \mathrm{~V}$; the maximum power densities of the SFFSB and CASFF were 0.615 and $0.497 \mathrm{~W} / \mathrm{cm}^{2}$ at a cell's voltage of $0.47 \mathrm{~V}$, respectively, demonstrating an improvement of $23.74 \%$ in the new SFFSB. The current density distribution verified the PEFC's performance improved by URC with the new SFFSB. The new SFFSB was determined to realize more balanced reactants concentration distribution from inlet to outlet and to activate the electrochemical reaction by increasing mass transport rates of reactants from flow channel to inner catalyst layer and by facilitating liquid water removal from URC regions. URC will play a significant role in improving PEFC's performance, furthermore, increasing the fuel cell lifetime. 
Keywords: Polymer electrolyte fuel cell; Serpentine flow-field; Under-rib convection; Maximum performance test; Current density distribution

\section{$\underline{\text { FULL TEXT }}$}

(C) 2019 The Authors. Published by ESG (www.electrochemsci.org). This article is an open access article distributed under the terms and conditions of the Creative Commons Attribution license (http://creativecommons.org/licenses/by/4.0/). 